\title{
Diversity, Abundance, and Distribution of Cladocera at the end of the Tigris River North of Basrah - IRAQ
}

\author{
Shaker G. Ajeel *
}

Mohammad F. Abbas

Received 5/10/2018, Accepted 12/3/2019, Published 1/12/2019

This work is licensed under a Creative Commons Attribution 4.0 International License.

\begin{abstract}
:
Seasonal variations of the species composition and abundance of Cladocera were studied in two stations at the end of the Tigris River and one station at the confluence of the Tigris with Euphrates area, at the beginning of the Shatt Al-Arab River in Al-Qurnah North of Basrah Province, from October 2015 to August 2016. Samples of zooplankton were collected by plankton net $100-\mu \mathrm{m}$. mesh size. The population density of Cladocera ranged between $1 \mathrm{Ind} / \mathrm{m}^{3}$ during summer and $211 \mathrm{Ind} . / \mathrm{m}^{3}$ during winter at station 1 (Al-Jewaber Bridge). A total of 16 species of Cladocera belonging to 12 genera were recorded in the study. The average density of Cladocera ranged from $23.2 \mathrm{ind} . / \mathrm{m}^{3}$ at Station 2 (Hamayon Bridge) to $53.7 \mathrm{Ind} . / \mathrm{m}^{3}$ at Station 1 (Al-Jewaber Bridge). The results showed that the Bosmina meridionalis was dominant at the three stations $47.8 \%$, while the other species were as follow Moina affinis 15.1\%, Daphnia lumholtzi 9.3\%, Simocephalus (Simocephalus) vetuloides $8.1 \%$ and Daphnia exilis $6.6 \%$ of the total Cladocera.
\end{abstract}

Key words: Abundance, Cladocera, Distribution, Tigris River, North of Basrah.

\section{Introduction:}

Tigris River originates from the Taurus Mountains, southeast of Turkey. The length of the river is about $1,718 \mathrm{Km}$, four hundred kilometers in Turkish territory, Fifty kilometers in Syrian territory and $1400 \mathrm{Km}$ in Iraqi territory. The Tigris River joins with the Euphrates River in the south of Iraq at Al-Qurna City and Garmat Ali, to form Shatt AlArab, this flows into the Arabian Gulf (1).

Cladocerans (water fleas) are primarily freshwater small-sized $(0.2-6 \mathrm{~mm})$, branchiopod crustaceans, inhabiting pelagic and littoral zones. Four cladocerans orders are recognized (2) and about 620 species are currently known. They inhabit most types of continental fresh and saline water habitats, occurring more abundantly in both temporary and permanent stagnant waters (3).

The Cladocera have an important and active role in the ecosystem because of its location in the food chain between phytoplankton and fish and predatory invertebrates, and considered an important food for fish, especially small fish, as well as an indicator to the environmental condition because of its sensitivity to any changes happening in the environment $(4 ; 5)$.

In Iraq, the researchers began studying zooplankton about 97 years ago.

Department of Marine Biology, Marine Science Centre, University of Basrah, Basrah, Iraq

"Corresponding author: shaker_ajeel@yahoo.com
The first research was published by Gurney (6), in which about 40 species of aquatic invertebrates were collected by Dr. Bu Buxton and reported during 1917 and 1918 in Amara Province and its environs. They recorded eighteen species of Cladocera. Then Mohammad (7) study in the center and south of Iraq, recorded 23 species of the Cladocera, including 15 species as a first record in Iraq. Whereas AL-Hammed (8) and Khalaf \& Smirnov (9) study in central and southern Iraq, the study included twenty-three species of the Cladocera as well as other species. Also Khalaf et al. (10) studied the seasonal variations in the density of two species of water fleas in the marine fish farm in Zaafaraniyah City with some environmental factors such as air temperature and dissolved oxygen.

Mohammad (11) concluded that species of the Cladocera are predominant within the zooplankton of the Euphrates River in Fallujah while the Copepoda was dominated in the Tigris River in Baghdad. Salman et al. (12) showed seasonal differences of zooplankton in the Shatt AlArab River and they found that the Cladocera was dominant followed by the Copepoda. In the Garma marshes Al Saboonchi et al. (13) recorded seven species of Cladocera. Mohammad (14) found thirteen species of the Cladocera in the Tigris River in Baghdad, and while Mangalo \& Akbar (15) found eighteen species were recorded in the 
Euphrates in Falluja .Al-Zubaidi (16) reported, the Cladocera is more abundant than other zooplankton groups in Shatt Al-Arab. Ajeel (17) stated that Cirripede larvae were dominant in Shatt Al-Arab, followed by the Cladocera. Whereas in Garmat Ali River the Copepoda were dominant followed by Cladocera (18), and in Shatt Al-Arab River (AlAshar) the Cladocera were dominant constituting $73 \%$ of the total zooplankton (19).

The current study is conducted to show the importance of zooplankton in the aquatic environment and to reinforce studies of this group of zooplankton in different areas of Basrah and to know the distribution of Cladocera and to monitor the effects of some physical and chemical parameters on abundance of this group.

\section{Materials and methods Study area}

This study was carried out seasonally from three stations South Tigris River, North of Basrah between October 2015 and August 2016 Fig. 1. The first station located near Al-Jewaber Bridge ( $31^{\circ} 0953^{\prime} 0.45 " \mathrm{~N}$ and $47^{\circ} 2556^{\prime} 0.89$ "E). The second station near Hamayon Bridge ( $31^{\circ}$ 0748' $0.15 " \mathrm{~N}$ and $47^{\circ} 2638^{\prime} 0.79$ "E) and the third station at the confluence of Euphrates and Tigris area in Al-Qurna region $\left(31^{\circ} 0042^{\prime} 71^{\prime \prime} \mathrm{N}\right.$ and $47^{\circ} 2623^{\prime}$ 0.23 "E).

\section{Sample collection}

Zooplankton samples were collected seasonally from surface water by using zooplankton conical tow net, mesh-sized $100 \mu \mathrm{m}$ and having a mouth aperture of $40 \mathrm{~cm}$ in diameter. A digital flow-meter was mounted in the middle of the mouth of the zooplankton net. The net was horizontally towed behind a boat running at its lowest speed for 10-15 minutes, and then collect the zooplankton that have been retained by the net. The reading of the flow meter was taken before and after towing. At each station, samples of zooplankton were collected, transferred to containers (plastic bottles). The plankton samples were immediately fixed in $4 \%$ formaldehyde (20).

Water temperatures were measured by a thermometer with $0.1^{\circ} \mathrm{C}$. Salinity and $\mathrm{pH}$ measurements were performed by YSI 556 MPS. Dissolved oxygen concentrations were measured by Winkler method. Turbidity was measured by HANNA instrument, Microprocessor Turbidity Meter HI 93703.

In the laboratory, samples were poured into a graduated vessel, and diluted if densely populated. Then a $10 \mathrm{ml}$ subsample was taken and placed in a Bogorov counting chamber (21), examined and counted under a compound and dissecting microscope. This procedure was repeated for 3 times, and then the whole sample was examined for the rare species. The volume of water was calculated using the method of (22).

Where:

$$
V=\Pi \mathbf{r}^{2} \mathbf{d}
$$

$\mathrm{V}=$ volume of water filtered by the net and is measured in cubic meters

$\Pi=(3.14)$

$\mathrm{r}=$ half diameter of the net mouth aperture $(20 \mathrm{~cm})$

$\mathrm{d}=$ number of revolutions of the flow meter multiplied at 0.3 .

Then the result was dividing by 10,000 to convert the result unite per cubic meters. The numbers of individuals were calculated in the sample diluted to $1000 \mathrm{ml}$ in the manner prescribed by (23), and expressed the result in cubic meter.

No. $/ \mathrm{m}^{3}=$ (C X VI ) / ( VII X VIII $)$

Where:

$\mathrm{C}=$ the number of individuals in the subsample

$\mathrm{VI}=$ volume of sample $(\mathrm{ml})$.

$\mathrm{VII}=$ the size of the subsample $(10 \mathrm{ml})$.

VIII $=$ volume of water filtered in cubic meters 


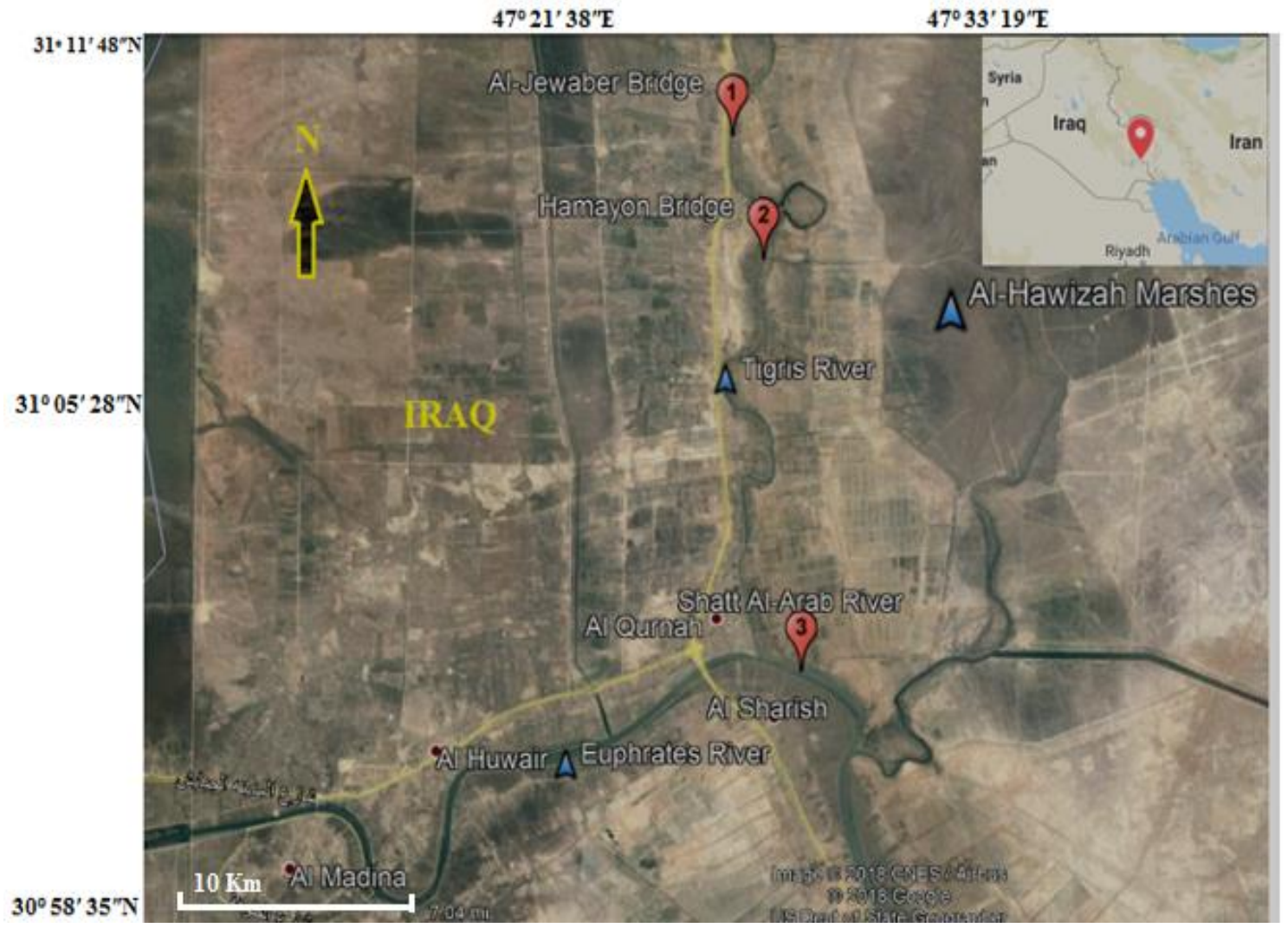

Figure 1. Map of the study area taken by using Google Earth program.

\section{Ecological Indices}

\section{1- Diversity index $(\mathrm{H})$ Shannon -Weaner}

The diversity index $(\mathrm{H})$ was calculated from the equation of Shannon-Weaner (24) as follows:

Where:

$$
\bar{H}=-\sum(\mathbf{n i} / \mathbf{N}) \ln (\mathbf{n i} / \mathbf{N})
$$

$\mathrm{ni}=$ Number of members of the same species $\mathrm{N}=$ The total number of individuals in the sample

\section{2 - Evenness (J)}

Evenness $(\mathrm{J})$ was calculated by the equation of Pielou (25):

Where:

$$
\mathbf{J}=\mathbf{H} / \ln \mathbf{S}
$$

$\mathrm{H}=$ Shannon Weaner diversity index

$\mathrm{S}=$ Number of species

\section{3 - Richness index (D)}

Richness was calculated by the equation of Margalef (26) as follows: -

$$
D=S-1 / \ln N
$$

Where:

$\mathrm{D}=$ richness index

$\mathrm{S}=$ total number of species

$\mathrm{N}=$ total number of individuals

\section{Results:}

Hydrographic features of the stations

The water temperatures at three stations were very close to each other, ranging between 9.5 ${ }^{\circ} \mathrm{C}$ (in January 2016) at Station 1 (Al Jewaber Bridge) and $37.5^{\circ} \mathrm{C}$ (in the summer 2016) at Station 3 (Shatt Al-Arab). Salinity changed from $1 \%$ at station 2 (Hamayon Bridge) to 1.8\%o at station 3. $\mathrm{pH}$ ranged from $7.5-8.2$ and dissolved oxygen from $6 \mathrm{mg} / \mathrm{L}$ at station 3 to $8.7 \mathrm{mg} / \mathrm{L}$ at station 1 . While the highest value of turbidity was 99.8 NTU during the winter at station 1 , and the lowest 8.8 NTU was recorded during spring at station 3 (Fig. 2). 


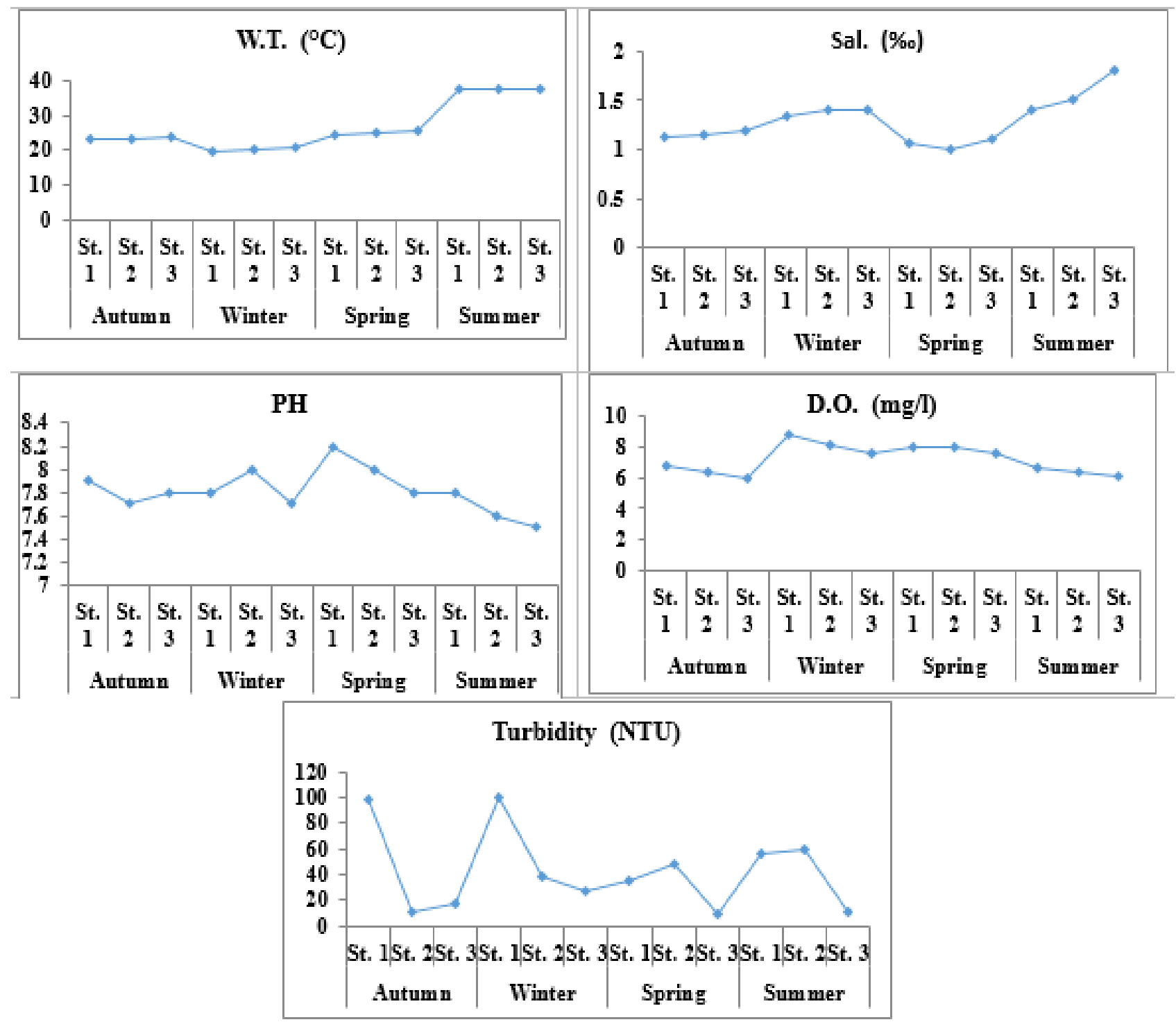

Figure 2. Water temperatures, Salinity, pH, dissolved oxygen and turbidity at the end of Tigris River between October 2015 and August 2016.

\section{Station 1}

A total of 10 species of Cladocera belonging to 9 genera were recorded at this station. The density of Cladocera ranged from $1 \mathrm{Ind} . / \mathrm{m}^{3}$ (in Summer) to $211 \mathrm{Ind} . / \mathrm{m}^{3}$ (in Winter) (Table 1). The average of seasonal density was $54 \mathrm{Ind} . / \mathrm{m}^{3}$. The highest peak was recorded by Bosmina meridionalis at Winter $\left(116 \mathrm{Ind} . / \mathrm{m}^{3}\right)$ which comprised $54.5 \%$ of total Cladocera followed by Daphnia lumholtzi $19.4 \%$, Daphnia exilis 12.9\%, Simocephalus (Simocephalus) vetuloides $9.7 \%$ and Alona costata 2.3\% (Fig. 3).

Table 1. Seasonal Cladocera density (Ind./m³) at St. 1 (Al-Jewaber Bridge)

\begin{tabular}{clcccc}
\hline \multicolumn{1}{c}{ Species of Cladocera } & Autumn & Winter & Spring & Summer \\
\hline 1 & Alona costata & 1 & 4 & 0 & 1 \\
2 & Bosmina meridionalis & 0 & 116 & 2 & 0 \\
3 & Camptocercus rectirostris & 0 & 0 & 1 & 0 \\
4 & Daphnia exilis & 0 & 28 & 0 & 0 \\
5 & Daphnia lumholtzi & 0 & 42 & 0 & 0 \\
6 & Dunhevedia crassa & 0.1 & 0 & 0 & 0 \\
7 & Ilyocryptus agilis & 0 & 0.02 & 0 & 0 \\
8 & Moina affinis & 0.1 & 0 & 0 & 0 \\
9 & Pleuroxus paraplesius & 0.1 & 0 & 0.01 & 0 \\
10 & Simocephalus (Simocephalus) vetuloides & 0 & 21 & 0.02 & 0 \\
\multicolumn{2}{r}{ Total Cladocera } & $\mathbf{1 . 3}$ & $\mathbf{2 1 1 . 0 2}$ & $\mathbf{3 . 0 3}$ & $\mathbf{1}$ \\
\hline
\end{tabular}




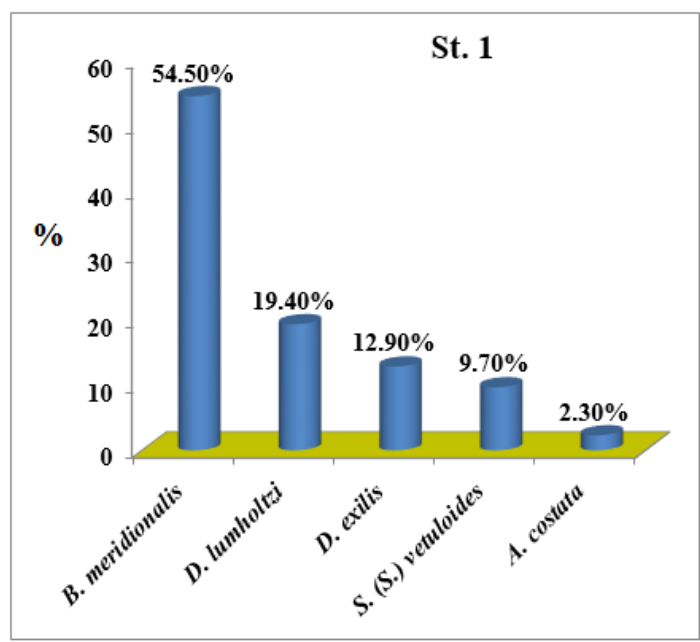

\section{Station 2}

Fifteen species of Cladocera belonging to 12 genera were recorded in this station. The density of Cladocera ranged from $3 \mathrm{Ind} . / \mathrm{m}^{3}$ (in Summer) to 72.5 Ind. $/ \mathrm{m}^{3}$ (in Winter) (Table 2). The average seasonally density was $24.4 \mathrm{Ind} . / \mathrm{m}^{3}$. The highest peak belonged to Bosmina meridionalis at Winter (47 Ind. $/ \mathrm{m}^{3}$ ) which comprised $48.1 \%$ of total Cladocera followed by Simocephalus (Simocephalus) vetuloides 9.5\%, Moina affinis $7.2 \%$, Alona costata $5.4 \%$ then Camptocercus rectirostris and Pleuroxus paraplesius 5.1\% (Fig. 4).

Figure 3. Percentages of dominant species of Cladocera at St. 1 (Al-Jewaber Bridge).

Table 2. Seasonal Cladocera density $\left(\mathrm{Ind} . / \mathrm{m}^{3}\right)$ at $\mathrm{St} .2$ (Hamayon Bridge)

\begin{tabular}{llcccc}
\hline \multicolumn{1}{c}{ Species of Cladocera } & Autumn & Winter & Spring & Summer \\
\hline 1 & Alona costata & 0.1 & 3.2 & 1 & 1 \\
2 & Alona rustica rustica & 0 & 0 & 0.01 & 0 \\
3 & Bosmina meridionalis & 0 & 47 & 0 & 0 \\
4 & Camptocercus rectirostris & 2 & 2 & 1 & 0 \\
5 & Chydorus sphaericus sphaericus & 0 & 1 & 0.01 & 0.01 \\
6 & Daphnia exilis & 0 & 2 & 0 & 0 \\
7 & Daphnia hyalina & 0 & 2.1 & 0 & 0 \\
8 & Diaphanosoma brachyurum & 1 & 0.8 & 0 & 0 \\
9 & Dunhevedia crassa & 2 & 0 & 0 & 1 \\
10 & Ilyocryptus agilis & 0 & 0.2 & 0 & 0 \\
11 & Moina affinis & 2 & 3 & 1 & 1 \\
12 & Pleuroxus paraplesius & 5 & 0 & 0 & 0 \\
13 & Scapholeberis kingi & 0 & 3.2 & 1 & 0 \\
14 & Simocephalus (Echinocaudus) exspinosus & 0 & 0 & 3 & 0 \\
15 & Simocephalus (Simocephalus) vetuloides & 0.1 & 6.2 & 3 & 0.01 \\
\multicolumn{2}{r}{ Total Cladocera } & $\mathbf{1 2 . 2}$ & $\mathbf{7 2 . 5}$ & $\mathbf{1 0 . 0 2}$ & $\mathbf{3 . 0 2}$ \\
\hline
\end{tabular}

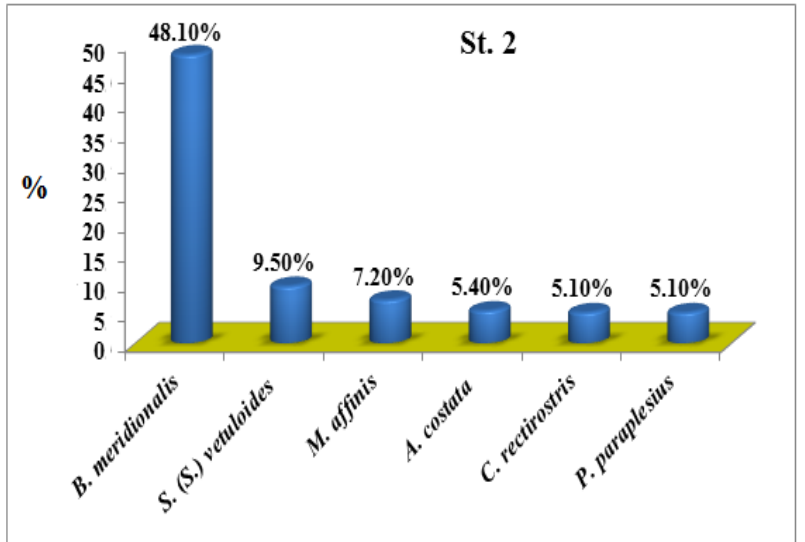

Figure 4. Percentages of important species of Cladocera at St. 2 (Hamayon Bridge).

\section{Station 3}

A total of 15 species of Cladocera belonging to 11 genera were recorded in this station. The density of Cladocera ranged from 26 Ind. $/ \mathrm{m}^{3}$ (in Summer) to $88 \mathrm{Ind} . / \mathrm{m}^{3}$ (in Winter) (Table 3 ). The average seasonal density was 47 Ind. $/ \mathrm{m}^{3}$. The highest peak belonged to Bosmina meridionalis at Winter (72 Ind. $/ \mathrm{m}^{3}$ ) which comprised $38.7 \%$ of total Cladocera followed by Moina affinis $35.6 \%$, Diaphanosoma brachyurum $6.9 \%$ and Simocephalus (Simocephalus) vetuloides 5.3\%, (Fig. 5). 
Table 3. Seasonally Cladocera density $\left(\mathrm{Ind} . / \mathrm{m}^{3}\right)$ at $\mathrm{St} .3$ (Al-Qurna region)

\begin{tabular}{llcccc}
\hline \multicolumn{1}{c}{ Species of Cladocera } & Autumn & Winter & Spring & Summer \\
\hline 1 & Alona costata & 0 & 3 & 0 & 1 \\
2 & Alona rustica rustica & 0 & 0 & 1 & 0 \\
3 & Bosmina meridionalis & 0 & 72 & 1 & 0 \\
4 & Camptocercus rectirostris & 1 & 0 & 1 & 0 \\
5 & Chydorus sphaericus sphaericus & 0 & 0 & 1 & 0 \\
6 & Daphnia exilis & 0 & 3 & 0 & 0 \\
7 & Daphnia hyalina & 0 & 3 & 1 & 0 \\
8 & Daphnia lumholtzi & 0 & 4 & 0 & 0 \\
9 & Diaphanosoma brachyurum & 10 & 0 & 2 & 1 \\
10 & Dunhevedia crassa & 1 & 0 & 0 & 0 \\
11 & Ilyocryptus agilis & 0 & 1 & 0 & 0 \\
12 & Moina affinis & 25 & 0 & 18 & 24 \\
13 & Pleuroxus paraplesius & 3 & 0 & 0 & 0 \\
14 & Simocephalus (Echinocaudus) exspinosus & 0 & 0 & 1 & 0 \\
15 & Simocephalus (Simocephalus) vetuloides & 4 & 2 & 4 & 0 \\
\multicolumn{2}{r}{ Total Cladocera } & $\mathbf{4 4}$ & $\mathbf{8 8}$ & $\mathbf{3 0}$ & $\mathbf{2 6}$ \\
\hline
\end{tabular}

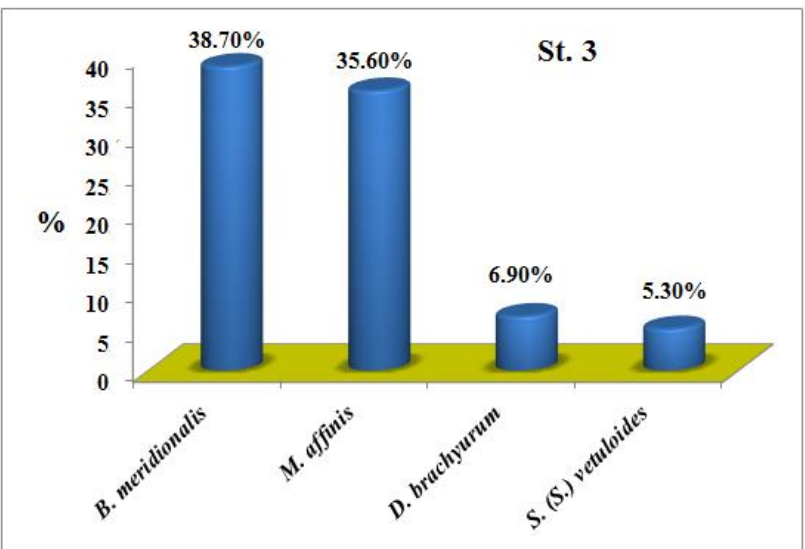

Figure 5. Percentages of important species of Cladocera at St. 3 (Al-Qurna region)

\section{Cladocera}

In the study, we recorded 16 species of Cladocera belonging to 12 genera. The average density of Cladocera ranged between $23.2 \mathrm{Ind} . / \mathrm{m}^{3}$ in Station 2 and 53.7 Ind. $/ \mathrm{m}^{3}$ in Station 1 (Table 4). The average density was 41.2 Ind. $/ \mathrm{m}^{3}$ and constituted $35.2 \%$ of total zooplankton in all three stations. The results showed that the Bosmina meridionalis was dominant in the three stations (47.8\%), the second important species was Moina affinis 15.1\%, Daphnia lumholtzi 9.3\%, Simocephalus (Simocephalus) vetuloides $8.1 \%$ and Daphnia exilis $6.6 \%$ of the total Cladocera (Fig 6).

Table 4. Average density of Cladocera (Ind./ $\mathrm{m}^{3}$ ) at three stations (Al-Jewabwe Bridge, Hamayon Bridge and Al-Qurna region) at the end of the Tigris River

\begin{tabular}{llccc}
\hline \multicolumn{1}{r}{ Species of Cladocera } & St. 1 & St. 2 & St. 3 \\
\hline 1 & Alona costata & 1.2 & 1.3 & 1 \\
2 & Alona rustica rustica & - & 0.002 & 0.25 \\
3 & Bosmina meridionalis & 29.5 & 11.7 & 18 \\
4 & Camptocercus rectirostris & 0.2 & 1.2 & 0.5 \\
5 & Chydorus sphaericus sphaericus & - & 0.3 & 0.25 \\
6 & Daphnia exilis & 7 & 0.5 & 0.7 \\
7 & Daphnia hyalina & - & 0.5 & 1 \\
8 & Daphnia lumholtzi & 10.5 & - & 1 \\
9 & Diaphanosoma brachyurum & - & 0.2 & 3.3 \\
10 & Dunhevedia crassa & 0.03 & 0.75 & 0.25 \\
11 & Ilyocryptus agilis & 0.005 & 0.05 & 0.25 \\
12 & Moina affinis & 0.03 & 1.7 & 16.7 \\
13 & Pleuroxus paraplesius & 0.03 & 1.2 & 0.7 \\
14 & Scapholeberis kingi & - & 0.8 & - \\
15 & Simocephalus (Echinocaudus) exspinosus & - & 0.7 & 0.25 \\
16 & Simocephalus (Simocephalus) vetuloides & 5.2 & 2.3 & 2.5 \\
\multicolumn{2}{r}{ Total Cladocera } & $\mathbf{5 3 . 7}$ & $\mathbf{2 3 . 2}$ & $\mathbf{4 6 . 6}$ \\
\hline
\end{tabular}




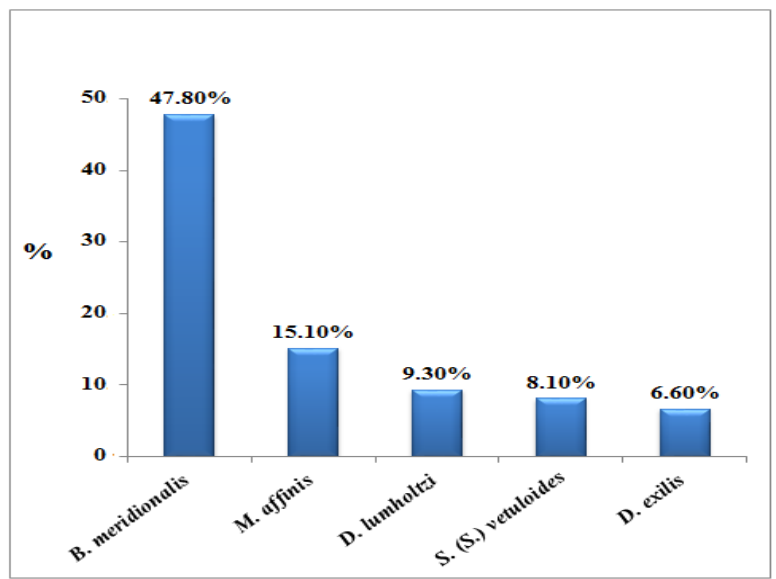

Figure 6. Percentages of important species of Cladocera at three stations (Al-Jewabwe Bridge, Hamayon Bridge and Al-Qurna region) at the end of Tigris River

\section{Ecological Indices}

\section{Diversity index (H) Shannon Weaner}

At St. 1, the highest value of diversity index was 1.22 occurring in Winter, while the lowest value 0.00 were recorded during Summer and the average value was 0.86 at St. 1 , whereas the highest rate 1.66 during Spring and the lowest rate 1.14 during Summer and the average 1.42 at second station, while at third station the diversity index ranged from $0.32-1.44$ at Summer and Spring respectively and the average was 0.94 (Fig 7).

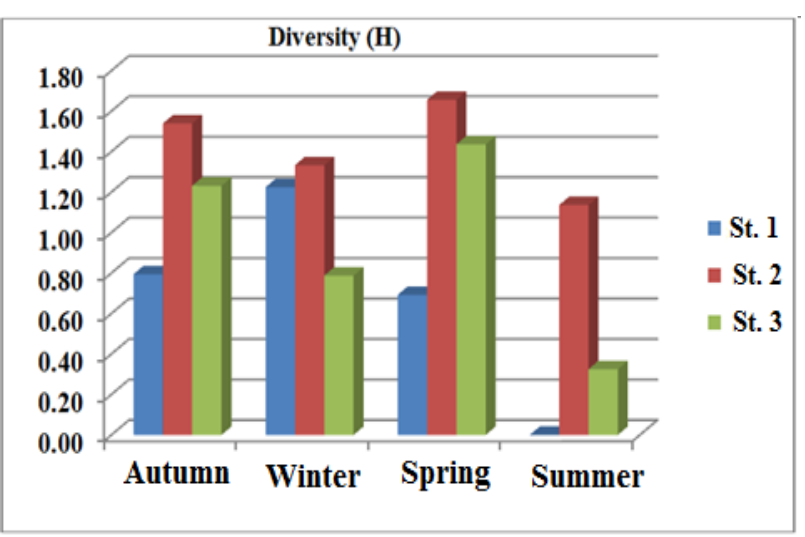

Figure 7. Seasonal variation in the Diversity $(\mathbf{H})$ of Cladocera during the period study at the end of Tigris River (St. 1 Al-Jewabwe Bridge, St. 2 Hamayon Bridge and St. 3 Al-Qurna region)

\section{Evenness (J)}

The highest value of evenness at St. 1 was 0.68 , recorded during Winter, while the lowest value was 0.00 recorded in Summer with average of 0.44 , At St. 2 the highest value of evenness was 0.80 and the lowest 0.56 during Spring and Winter respectively with average of 0.71 . Whereas at St. 3 the values of evenness ranged between 0.30 and
0.69 during Summer and Autumn respectively with average of 0.51 (Fig 8).

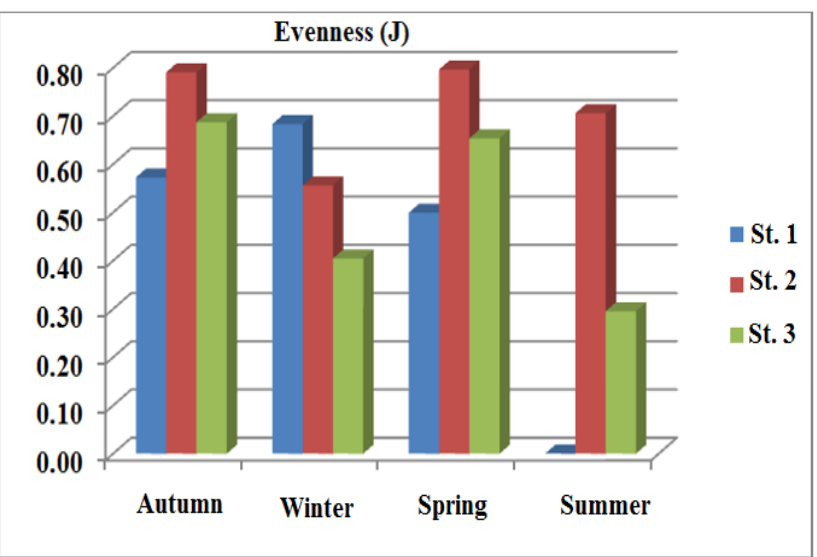

Figure 8. Seasonal variation in Evenness $(J)$ of Cladocera during the period study at three stations (St. 1 Al-Jewabwe Bridge, St. 2 Hamayon Bridge and St. 3 Al-Qurna region)

\section{Richness index (D)}

Richness values ranged from $0.00-0.79$ during Summer and Autumn respectively with average of 0.68 at station 1 , and $1.14-1.66$ during Summer and Spring respectively with average of 1.42 at station 2 , while at station 3 it ranged between 0.32 and 1.44 during Summer and Spring respectively with average of 0.94 (Fig 9).

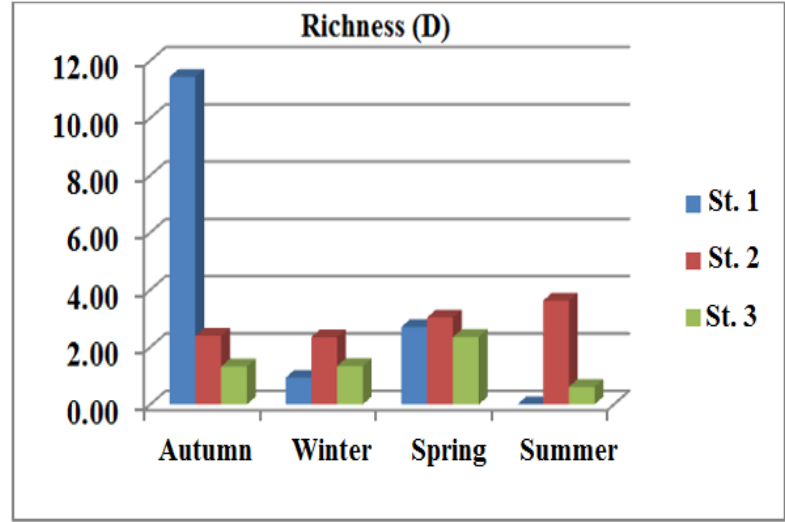

Figure 9. Seasonal variation in the Richness (D) of Cladocera during the period study at three stations (St. 1 Al-Jewabwe Bridge, St. 2 Hamayon Bridge and St. 3 Al-Qurna region)

\section{Jacquard's Index}

Jaccard's similarity index was calculated for the Cladocera at the three stations; the highest similarity value was between stations (2) and (3) while the lowest value of similarity was between stations (1) and (2) (Fig. 10). 


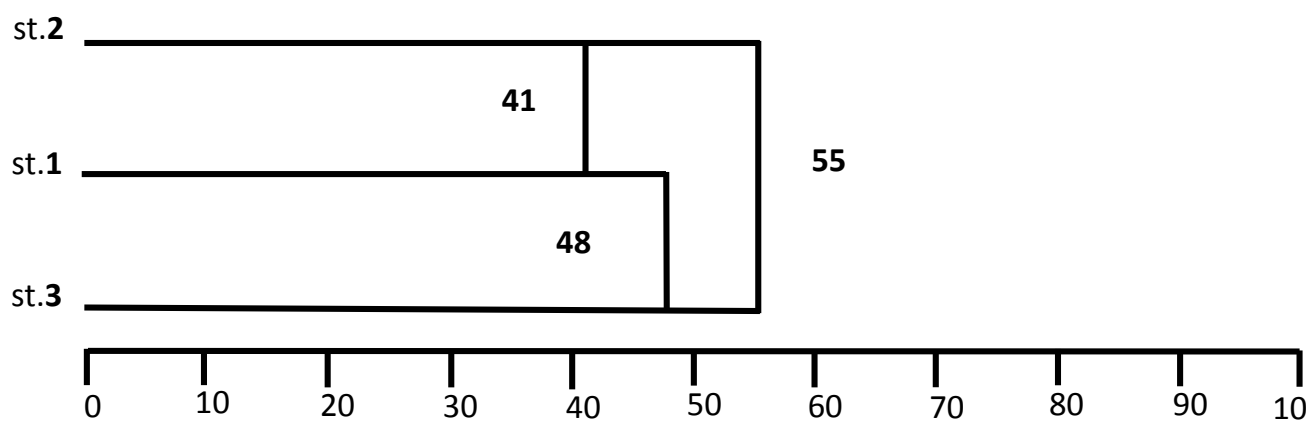

Figure 10. Cluster of the Similarity index (Jaccards) of the Cladocera during the period study at three stations (St. 1 Al-Jewabwe Bridge, St. 2 Hamayon Bridge and St. 3 Al-Qurna region)

\section{Discussion:}

The spatial and temporal distribution of zooplankton varies according to the prevailing environmental conditions in the region. Differences may also arise due to the nature of plankton distribution, also, irregularities that may be the cause of large differences in net (27). Moreover, the mesh-size of the net is an important factor controlling the quality and quantity of the catch. Environmental factors play an important role on the aquatic environment, water temperature affecting many properties through melting gases and salt (28).

The different uses of water and the rise of groundwater levels in the central and southern regions of Iraq lead to higher salinity rates. The highest value of salinity obtained at the third station (Shatt Al-Arab in Al-Qurna region) reaching $1.8 \%$. While the water discharged from the Tigris River decreases salinity, the lowest salinity value was at the first station (Al-Jewaber Bridge) reaching 1.0 $\%$. During the current study, the salinity and turbidity were not affected by temperature. The concentration of salinity increased from the first station towards the third station, while the turbidity reversed from the freshwater resource through Tigris River. This study is consistent with $(29,30)$.

The present results showed that there were differences in the abundance of Cladocera in the three stations sampled and showed a clear decrease in Cladocera density that may be due to temperature, abundance of the food and the pollution caused by human and agricultural activities. In addition the river flow has a significant impact on the densities of zooplankton as well as the amount of nutrients which impact the density of phytoplankton, which is the main food to the Cladocera. This leads to low densities and these results agree with Al-Jizani, (31), where he referred to the pollution that leads to a reduction of diversity and this is agree with most studies achieved on the water of Tigris River (32, 33 and 34). Station 1 (AlJewaber Bridge) apparently is the richest one, this is probably due to the presence of dense aquatic plants.

A low diversity of cladocerans can be found in this area, as well as in temporary water bodies, which may be related to the negative influence of human activities, and may lead to decrease of diversity or even local extinction of some species. The results showed that Bosmina meridionalis was dominant at three stations, this indicates that this species have wide range of tolerance to the different environmental conditions, whereas the species of Cladocera which were less abundante may have a narrow range of tolerance.

In the study area, it was observed that the Cladocera had the lowest densities during Winter then Autumn, Spring and Summer. While in the Garmat Ali River, it had the highest density during Summer followed by Spring then Autumn, and Winter (18). The salinity recorded in the current study ranged from $1.0-1.8 \%$ while, in the study of Ajeel et al. (18) it was $3.0 \%$. In addition, the difference in abundance of phytoplankton and environmental pollutants have an impact on the abundance of zooplankton in general.

It was observed that the highest density of Cladocera was $211 \mathrm{Ind} . / \mathrm{m}^{3}$ recorded at station 1 during Winter, whereas, Ajeel (35) recorded the lowest value in Garmat Ali River, where the current study, recorded 7207 Ind./m³ during April 1997, other previous studies such as: Salman et al. (12) recorded 520 Ind. $/ \mathrm{m}^{3}$ in January 1983 at Shatt AlArab, while in 1998 Al-Zubaidi (16) recorded the highest number of Cladocera in Shatt Al-Arab was 10854 Ind. $/ \mathrm{m}^{3}$ during August 1994. whereas Mangalo and Akbar (15) recorded $29 \mathrm{Ind} . / \mathrm{m}^{3}$ during April, in Tigris River near Baghdad City and 292 Ind. $/ \mathrm{m}^{3}$ in Diyala River in March. These differences in densities of Cladocera in different regions were due to the differences in environmental conditions and the differences in the mesh size that was used in the sampling. Table (5) shows densities of Cladocera in several areas in Basrah.

It has been shown through the present study that Cladocera species bloomed mainly during 
Spring followed by Autumn then Winter and Summer at all stations, and this result agrees with the study of Ajeel (35), and confirmed the results of the ecological indices the diversity index $(\mathrm{H})$ show high value during Spring at station 2, and decrease value during Summer at station 1, while, the values of Richness index (D) were high during Autumn and low during Summer at station 1. Whereas Evenness index (J) were high during Spring at station 2 and low during Summer at station 1. The high diversity may be attributed to the lack of pollution in this region and this is consistent with the conclusion drawn by Al-Jizani (31) who suggested that pollution leads to reduce the diversity index.

In the study area, 16 species of Cladocera were recorded, ten species were identified in station 1 and fifteen species in each of the other two stations. This is in accordance with the findings of Ajeel et al. (36) that fourteen species of Cladocera were identified in the nearby region of southern marshes (Hour Al-Hammar) of Iraq. Similarly, in Shatt Al-Arab estuary towards Al-Amara City, 14 species were also reported (6). While Tigris River recorded 25 species (37) and 23 species were recorded in Shatt Al-Arab River (35), 20 species in Al-Hawiza marshes and Al-Izze river (36) whereas 19 species in Shatt Al-Arab River and 15 species in Garmat Ali River (32), 12 species in Garmat Ali River (18), 8 species in Shatt Al-Basrah (38), 5 species in Shatt Al-Arab (39).

Table 5. Density of Cladocera (ind. $/ \mathrm{m}^{3}$ ) in Basrah Province reported by various authors

\begin{tabular}{cccc}
\hline Locality & $\begin{array}{c}\text { Mish - } \\
\text { size }(\mathbf{m m})\end{array}$ & $\begin{array}{c}\text { Cladocera } \\
\left(\mathbf{I n d} . \mathbf{m}^{\mathbf{3}}\right)\end{array}$ & References \\
Shatt Al-Arab & 0.090 & $0.3-229$ & 35 \\
Shatt Al-Arab & 0.090 & $4-10854$ & 16 \\
Shatt Al-Arab & 0.090 & $0.3-2560$ & 40 \\
Garmat Ali & 0.090 & $17.5-12539$ & 40 \\
Garmat Ali & 0.250 & $3-98$ & 18 \\
Shatt Al-Arab & 0.120 & $0-2118$ & 17 \\
Shatt Al-Basrah & 0.120 & $0-5$ & 17 \\
Al-Qurna & 0.120 & $1.27-2435$ & 41 \\
Al-Hartha near & & & \\
the paper mill & 0.120 & $1.2-91225$ & 41 \\
Factory & & & \\
Shatt Al-Basrah & 0.120 & $0-5267$ & 38 \\
Aboflos & 0.120 & 11216 & 42 \\
Al-Seba & 0.085 & $0-1640$ & 21 \\
Al-Faw & 0.085 & $0-425$ & 21 \\
Al-Ashar & 0.085 & $0.01-18922$ & 39 \\
Abu Al-Khasib & 0.085 & $4.9-818$ & 39 \\
End of Tigris & 0.100 & $1-211$ & Present study \\
River & & & \\
The confluence & & & \\
of the Tigris & 0.100 & $26-88$ & Present study \\
and Euphrates & & & \\
at Al-Qurna & & &
\end{tabular}

\section{Conclusions:}

The results of the current study showed that a low diversity of cladocerans can be found in this area, and Bosmina meridionalis was dominant at the three stations. This indicate that these species have wide range of tolerance to the different environmental conditions, whereas those species of Cladocera which were rare in abundance such as $A$. costata, $C$. rectirostris, $P$. paraplesius, $D$. brachyurum and $S$. (S.) vetuloides may have narrow range of tolerance to these environmental conditions.

\section{Conflicts of Interest: None.}

\section{References:}

1. Al-Aani KS. Geography of Iraq, Baghdad University Press, 1979; 23.

2. Fryer G. Morphology and the classification of the socalled Cladocera. Hydro. 1987; 145: 19-28.

3. Forro L, Korovchinsky NM, Kotov AA, Petrusek A. Global diversity of cladocerans (Cladocera; Crustacea) in freshwater. Hydro. 2008; 595:177-184.

4. Monaghan KA, Milner AM. Effect of Anadromous salmon red construction on marcoinvertebrate communities in a recently formed stream in coastal Alaska .J. North Am. Benthol. Soc. 2010; 28:153166.

5. Lotter AF, Heiri O, Brooks S, van Leeuwen JF, Eicher U, Ammann B. Rapid summer temperature changes during Termination Ia: high-resolution multiproxy climate reconstruction from Gerzensee (Switzerland).Quaternary Science Re- views. 2012; 36,103-113.

6. Gurney R. Fresh water crustacean collected by Dr. P.A. Buxton in Mesopotamia and Persia. Bombay Nat. Hist. Soc. 1921; 27: 835 - 843.

7. Mohammed MB. A Faunal study of the Cladocera of Iraq. Bulletin of the biological Res. Center. 1965; 1: $1-11$.

8. Al-Hamed MI. Limnological study on the inland water of Iraq. Bull. Iraq Nat. Hist. Mus. 1966; 3: 121.

9. Khalaf AN, Smirnov NN. On littoral Cladocera of Iraq. Hydrobiology. 1976; 51: 91- 94.

10. Khalaf AN, Lattif MA. Mangalo HH. Growth of Simocephalus vetulus Schodler (Crustacea: Cladocera) under different diet conditions. Bull. Biol. Res. Cont. 1977; 9: 17-26.

11. Mohammed MB. Ahydrobiological survey of a polluted canal. Hydrobiology. 1980; 74:179-186.

12. Salman SD, Marina BA, Ali MH, Oshana VK. Zooplankton studies. In final report the 18. Month marina pollution monitoring and research programming in Iraq. Marine science center of Basrah University Iraq. 1986; 156 - 166.

13. Al - Saboonchi AA, Barak NA, Mohamed AM. Zooplankton of Garmma marshes. Iraq J. Biol. Sci. Res. 1986; 17 (1): 33 - 40.

14. Mohammad MB. Associations of invertebrates in the Euphrates and Tigris Rivers at Falluja and Baghdad 
Iraq. Archive. Fur Hydrobiology. 1986; 106 (3): 337350 .

15. Mangalo HH, Akbar MM. Comparative study of two populations of cladocerans in the Tigris and Diyala Rivers at Baghdad. J. Biol. Sci. Res. 1988; 19 (1): 117-128.

16. AL-Zubaidi AMH. Distribution and abundance of the zooplankton in the Shatt AL-Arab estuary and Northwest Arabian Gulf. Ph. D. thesis, University of Basrah. 1998.

17. Ajeel SG. Abundance and distribution of zooplankton in some waters in southern region of Iraq. Marina Mesopotamica. 2004; 19(1): 95-115.

18. Ajeel SG, Abdulla SB, Mohammad HH. Abundance and distribution of the zooplankton in the Garmat-Ali River. Basrah J. of Agricultural Science. 2004; 17(1): 167-178.

19. Ajeel SG. Seasonal variations of zooplankton abundance in Shatt Al-Arab River, Southern Iraq, Inter. J. Marine Science. 2016; 6(58): 1-8.

20. Kamaladasa AI, Jayatunga YNA. Composition, density and distribution of zooplankton in South West and East Lakes of Beira Lake soon after the restoration of South West Lake. Cey. J. Sci. (Bio. Sci.). 2007; 36 (1):1-7.

21. Jebir AM. Ecological study of zooplankton in the Shatt Al-Arab River and Shatt Al-Basrah Canal South Iraq. M.Sc. Thesis. University of Basrah. 2013; P 119 (in Arabic).

22. DeBernardi R. Methods for the estimation of Zooplankton abundance. In: Downing, J.A. and RigIer, F.H. (eds.). A manual on methods for the assessment of secondary Productivity in freshwaters. BP Hand book No. 17 Blakwell, Oxford. 1984; 5586.

23. American Public Health Association. Standard methods for the examination of water and wastewater. 21-st edition Washington, Dc. 2006; $1400 \mathrm{pp}$.

24. Shannon CE, Weaver W. The mathematical theory of communication, Univ. Illinois press, Urbana, I. 1949; 11. $117 \mathrm{pp}$.

25. Pielou EC. Shannon's formula as measure of specific diversity: Its use and misuse. Am. Nat. 1966; 100: 463-465.

26. Margalef R. Perspectives in ecology theory. Univ. Chicago press, Chicago. 1968; 111 pp.

27. Raymont JEG. Plankton and productivity in the Ocean .П. Zooplankton Pergamon Press, 1983; 824 p.

28. Kinnesh MJ. Ecology of estuaries. Vol. 1, Physical and chemical aspects CRC press, Inc. Boca Raton, Florida. 1986; 254 pp.

29. Hussein NA, Al-Najjar HH K, Al-Saad HT, Yusuf $\mathrm{OH}, \mathrm{Al}-$ Sabonchi AA. Shatt Al- Arab Basic Scientific Studies, Marine Science Center Publications. University of Basra. 1991; 139pp. (in Arabic).
30. Al-Mahmood HKH, Al-Shawi EJ, Al-Amara FJM. Evaluation Changes in some physical and chemical properties of Shatt Al - Arab water. Basrah J. of Agricultural Science. 2008; (21): 433- 448.

31. Al-Jizani HRG. Organic pollution and its impact on the diversity and abundance of plankton in the Shatt Al-Arab, Al-Ashaar and Al-Robat channels M.Sc. Thesis, Education coll. Basrah Univ. 2005; 82 pp.

32. Rashid KA, Shehata HA. Sabri AW. Distribution and spread of zooplankton (Crustaceans) in the lower part of the Diyala River south of Baghdad. Diyala Journal of Scientific and Educational Research, Faculty of Education, Diyala University. 2000; 8 (1): 1-14.

33. Abbas AK, Al-Lami AAZ .The qualitative and quantitative composition of the Cladocera in the Tigris River - Iraq. Journal of Faculty of Education. 2001; 12 (4): 447-480.

34. Rajagopal T, Thangamani A, Serakodiyone SP, Sekar M, Archunan G. Zooplankton diversity and physicChemical Southern Baghdad, Thesis of ph. University of Baghdad, Iraq. 2001; 183pp.01.

35. Ajeel SG. Population dynamics and bioenergetics of two species of Cladocera (Simocephalus vetulus \& Daphnia magna) in Basrah with a reference to zooplankton. Ph.D. Thesis, University of Basrah. 1998; 154 pp. (in Arabic).

36. Ajeel SG, Khalaf TA, Mohammad HH, Abbas MF. Distribution of zooplankton in the Al-Hawizah, AlHammar marshes and Al-Izze River South of Iraq. Marsh Bulletin. 2006; 2: 140-153

37. Sabri AW, Ali ZH, Shawkat SF, Thejar LA, Kassim TI, Resheed KA. Zooplankton population in the River Tigris. Effects of Samara Impoundment. Regulated Rivers: research and management. 1993; 8: 237 - 250.

38. Ajeel SG. Distribution and abundance of zooplankton in Shatt Al-Basrah and Khour Al-Zubair Channels, Basrah, IRAQ. Journal of Basrah Researches ((Sciences)). 2012; 38(4): 10-28.

39. Ajeel SG, Abbas MF. Seasonal variations of the Cladocerans in the Shatt Al-Arab River, Southern Iraq. Iraqi J. Aquacult. 2016; 13 (1): 66 - 85.

40. Ajeel SG, Ali MH, Salman SD. Cladocera from Shatt Al-Arab and some temporary ponds in Basrah. Marina Mesopotamica. 2001; 16(1):309-329 (in Arabic).

41. Abbas MF. Abundance of Cladocera and some other zooplankton and Diversity in the Northern part of Shatt Al-Arab River. M.Sc. Thesis, College of Education, University of Basrah. 2010; 114 pp. (In Arabic).

42. Salman SD, Ali MH, Mohammad HH, Abbas MF. Zooplankton in the south of Iraq. Final report of discovery journey south Iraq waters during 1/7 4/7/2012. Marine Science Centre of Basrah University; Basrah, Iraq. 2012. 


\section{تتوع ووفرة وتوزيع متفرعة اللوامس في نهاية نهر دجلة شمال البصرة ــ العراق \\ محمد فارس عباس \\ شاكر غالب عجيل}

قسم الاحياء البحرية، مركز علوم البحار، جامعة البصرة، البصرة، العراق.

الخلاصة:

تم در اسة التغير ات النو عية والكمية لمتفر عة اللو امس في محطتين في نهاية نهر دجلة ومحطة واحدة في منطقة التقاء نهري دجلة

و الفرات في منطقة القرنة خلال الفترة من تثرين الاول

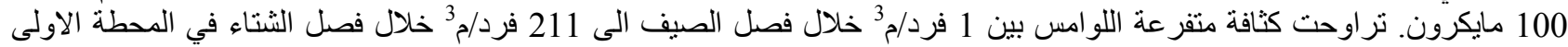

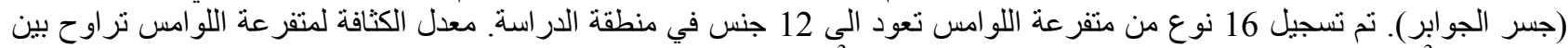

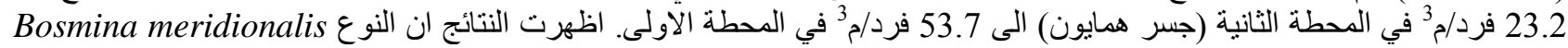

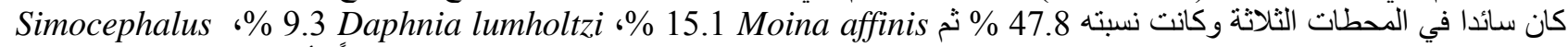

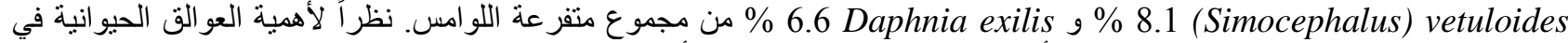
البيئة المائية ولتحديد توزيع متفر عة اللو امس وتأثير بعض العو امل البيئية عليها، أجريت هذه الدر اسة.

الكلمات المفتاحية: وفرة، متفر عة اللوامس، توزيع، نهر دجلة، شمال البصرة. 